\title{
Breeding seasonality and population dynamics of three rodent species in the Magamba Forest Reserve, Western Usambara Mountains, north-east Tanzania
}

\author{
Rhodes H. Makundi*, Apia W. Massawe and Loth S. Mulungu \\ Pest Management Center, Sokoine University of Agriculture, PO Box 3110, Morogoro, Tanzania
}

\begin{abstract}
We investigated breeding seasonality and population dynamics of three rodent species, Lophuromys flavopuncatus, Grammomys dolichurus and Praomys delectorum, in the Magamba Forest, Western Usambara Mountains, northeast Tanzania. Capture-mark-recapture studies were conducted in 2002-2004. Reproductive conditions of males and females showed temporal variations, an indication of breeding seasonality. Animals were reproductively active between February and May. Rainfall in November-January was instrumental for the onset of breeding and continued throughout the wet season. The recruitment of new individuals born during the season led to highest population densities between end of May and August. Populations declined progressively towards the end of the dry season (September-October). Only P. delectorum showed a marked density increase during January-February, indicating greater survival and/or recruitment during the NovemberJanuary rains. The study shows that despite a relatively stable environment of the forest reserve, rainfall has strong influence on reproduction and population dynamics, probably because of its effect on primary food resources.
\end{abstract}

Key words: breeding, dynamics, Grammomys, Lophuromys, Praomys, Tanzania

\section{Résumé}

Nous avons étudié la chronologie saisonnière de la reproduction et la dynamique de la population de trois espèces de rongeurs, Lophuromys flavopunctatus, Grammomys dolichurus et Praomys delectorum, dans la forêt de Magamba, dans

*Correspondence: E-mail: rmakundi@yahoo.com or rmakundi@suanet.ac.tz la partie ouest des monts Usambara, au nord-est de la Tanzanie. Des études par capture - marquage - re-capture ont été réalisées en 2002 - 2004. La condition reproductrice des mâles et des femelles présentait des variations saisonnières, un indice de saisonnalité de la reproduction. Les animaux étaient en état de reproduction active entre février et mai. Les chutes de pluie de novembre à janvier étaient très importantes pour le déclenchement de la reproduction et continuaient pendant toute la saison des pluies. Le recrutement de nouveaux individus nés durant cette saison conduisait à une densité de population qui culminait entre fin mai et août. Les populations déclinaient progressivement jusque vers la fin de la saison sèche (septembre - octobre). Seul $P$. delectorum montrait un taux de recrutement et/ou de survie plus élevé pendant les pluies de novembre à janvier. Cette étude montre que malgré l'environnement relativement stable de la réserve forestière, les chutes de pluie ont une forte influence sur la reproduction et la dynamique des populations, probablement à cause de leur effet sur les ressources primaires en nourriture.

\section{Introduction}

Tropical forests are home to a large diversity of small mammals including rodents. In East Africa, many studies have been conducted to provide insight into the ecology of rodents in these forests, particularly on how individuals, communities and species integrate with the environment (Happold, 2001). In the Usambara Mountains, north-east Tanzania, increasing human population has led to destruction of large proportions of natural forests, which directly threatens the existence of native species. Replacement of the natural forest by exotic tree plantations and other human activities including crop production, lead to modifications and fragmentation of habitats. Further, the 
creation of agro-forestry zones in the western Usambara Mountains has altered natural habitats, which directly affects among other parameters, species distribution and abundance (Makundi, Kilonzo \& Massawe, 2003). Apart from limiting the spatial distribution of rodents, these activities lower the survival of native species, and in the case of the Magamba Forest Reserve in north-east Tanzania, it has led to invasion by two opportunistic rodent species, the multimammate rats, Mastomys natalensis, and the grass rats, Arvicanthis nairobae (Makundi et al., 2003).

The relationship between reproduction and demography has been investigated and reported for several species of rodents in tropical Africa (e.g. Delany, 1971; Taylor \& Green, 1976; Hubert et al., 1981; Leirs, 1992; Leirs, Verhagen \& Verheyen, 1994). It has been shown that reproductive activity of rodents in rainforests is strongly related to the seasonal pattern of rainfall (Happold, 1977).

Earlier surveys (Makundi et al., 2003) of the Magamba Forest Reserve indicated the presence and abundance of three species of rodents, namely Lophuromys flavopunctatus, Grammomys dolichurus and Praomys delectorum. These surveys indicated that the spatial distribution and home range of the three species overlapped both in the rain forest and agro-forestry land at the edge of the forest (Makundi et al., 2003). The objective of the current study was to investigate the reproductive activity of the three species and their population dynamics in the Magamba Forest Reserve, north-east Tanzania. The study is part of an on-going longterm research on the ecology of rodents in Tanzania.

\section{Materials and methods}

Study site

The Magamba Forest Reserve $\left(04^{\circ} 70^{\prime} \mathrm{S}\right.$ and $\left.38^{\circ} 29^{\prime} \mathrm{E}\right)$ is a montane rain forest located in the Western Usambara mountains and within the Eastern Arc range of mountains in north-east Tanzania. It lies at an altitudinal range of 1500-1950 $\mathrm{m}$ a.s.l. The area covered by the forest reserve is $c$. 14,000 ha $(30,950$ acres), which is about $30 \%$ of the original forest. It is bordered by Shagayu (8900 ha) and Mkussu (4200 ha) forests, which are predominantly planted with pine trees.

\section{Trapping}

We conducted capture-mark-recapture (CMR) studies for a period of 2 years in a $100 \times 100 \mathrm{~m}$ grid located in the forest reserve at an altitude of $1750 \mathrm{~m}$. Animals were trapped for three consecutive nights at intervals of 4 weeks, using the Sherman live traps. The traps were baited with peanut butter mixed in maize bran and were inspected each morning. Captured animals were identified, weighed and the sex and sexual conditions were noted. Males were recorded as scrotal (descended testes) or abdominal. Females showed signs of pregnancy by palpation, had closed or perforated vaginas or were lactating. Animals were individually identified by toe clipping using specific number coding generated from CMR computer software and were later released at the point of capture.

\section{Analysis of data}

The density of animals per hectare was estimated for each 3-day trapping session using the $\mathrm{M}(\mathrm{h})$ Estimator of the program CAPTURE for a closed population, which allows for individual variations in trapping probability (White et al., 1982).

\section{Results}

\section{Praomys delectorum}

Sexually active female $P$. delectorum were present in higher numbers in the population during April-July (Fig. 1a). Pregnant females were trapped in May and June. Sexually active males (scrotal testes) were numerous in the population in March-June (Fig. 1b). Although few individuals remained in active reproductive conditions at different times of the year, peak numbers were present in the population during April. Juveniles were more numerous in the population during June and July and accounted for the high numbers of males with abdominal testes and females with a closed vagina (Fig. 1a,b).

\section{Lophuromys flavopunctatus}

Females with perforated vagina occurred in the population throughout the year (Fig. 2a). Males with scrotal testes were present predominantly during March-April and December-January (Fig. 2b). There was no strict seasonality in reproductively active individuals, but pregnant individuals were more numerous during April-May. Juveniles in nonreproductive condition were found in the population during July-August (Fig. 2a,b). 

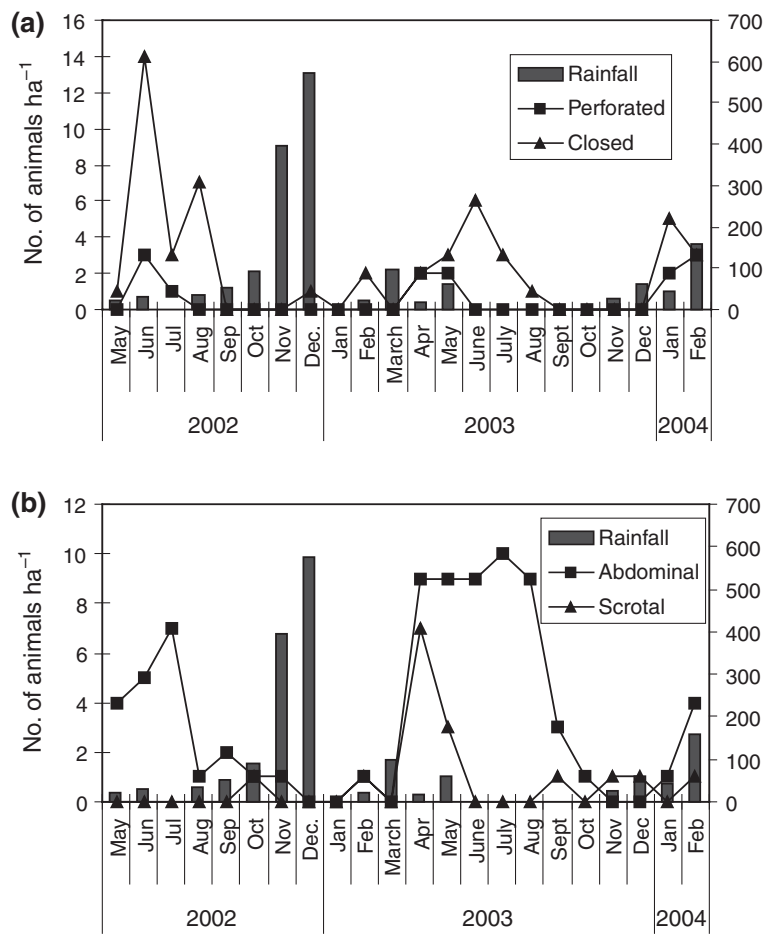

Fig 1 (a) Breeding conditions of female Praomys delectorum in the Magamba Forest Reserve, north-east Tanzania. (b) Breeding conditions of male P. delectorum in the Magamba Forest Reserve, north-east Tanzania

\section{Grammomys dolichurus}

Reproductively active females were present in the population during March-July (Fig. 3a). Males in scrotal condition were present in the population during February-July (Fig. 3b). Pregnant females were captured from April to July.

\section{Population dynamics}

Praomys delectorum was the most abundant species in the forest reserve. However, all the three species had periods of low and high density (Fig. 4). Density increases of the population of $P$. delectorum occurred between March and June, a period that coincided with greater reproductive effort of this species than in the rest of the year. The period December-February also recorded increasing density of P. delectorum during 2003-2004. Density increases for L. flavopunctatus occurred in June-August, whereas for G. dolichurus, this occurred in March-July. Densities of the individual populations of the three species were lowest
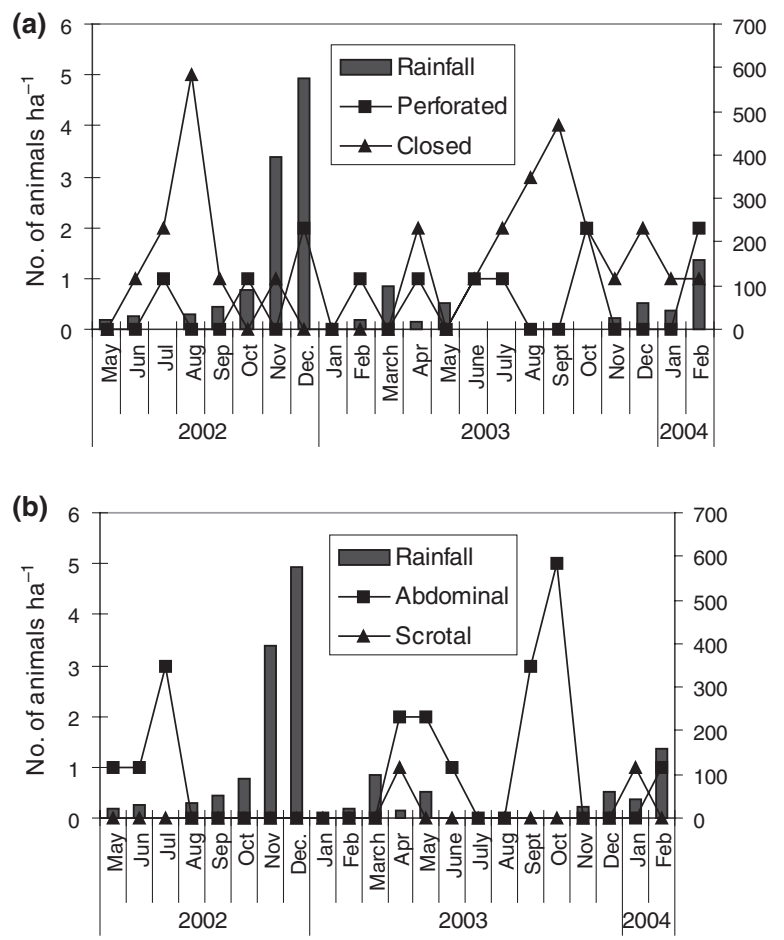

Fig 2 (a) Breeding conditions of female Lophuromys flavopunctatus in the Magamba Forest Reserve, north-east Tanzania. (b) Breeding conditions of male L. flavopunctatus in the Magamba Forest Reserve, north-east Tanzania

between September and December. The three species showed peak population abundance about 2-3 months after the onset of the rains in November/December (Fig. 4).

\section{Discussion}

The absolute numbers of reproductively active individuals in the population showed a decrease and increase at different times of the year. The population dynamics of the three species in this study showed density increases during the wet season and a decline in the dry season (AugustNovember) indicating that reproductive effort of the three species was highest when conditions were most favourable. Although reproductively active L. flavopunctatus were present in the population almost throughout the year, there was a seasonal peak after the wet season. Many rodent species usually have a specific well-defined period of reproduction, with a period of maximum reproductive activity, which may be short or long (Happold, 2001). Seasonal variations of weather, particularly rainfall, influence some nutritional aspects, which affect the life 

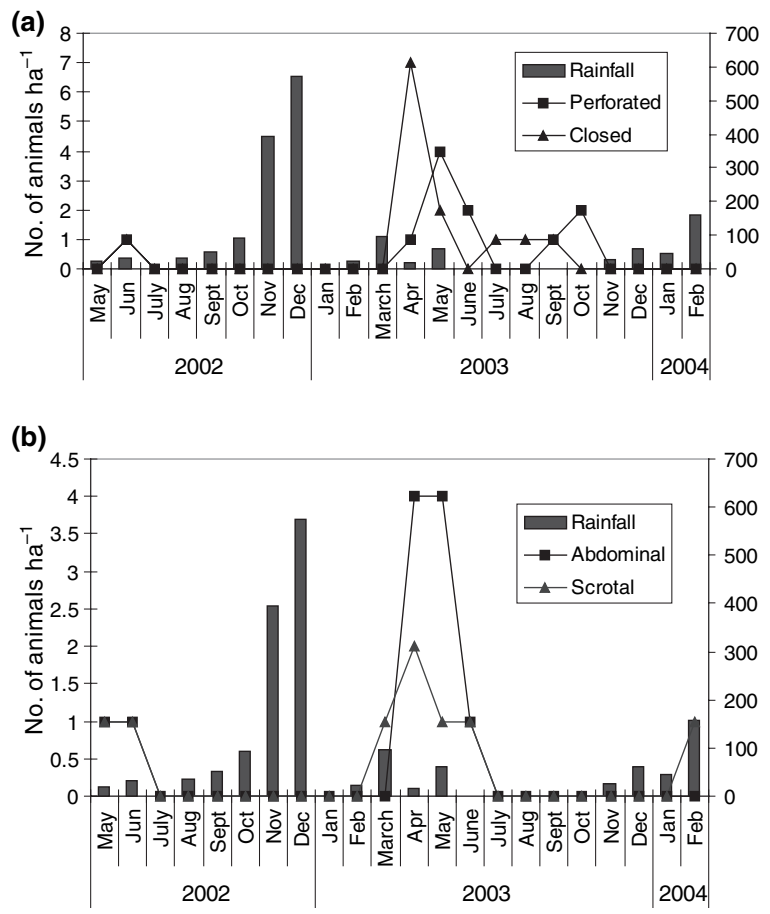

Fig 3 (a) Breeding conditions of female Grammomys dolichurus in the Magamba Forest Reserve, north-east Tanzania. (b) Breeding conditions of male G. dolichurus in the Magamba Forest Reserve, north-east Tanzania

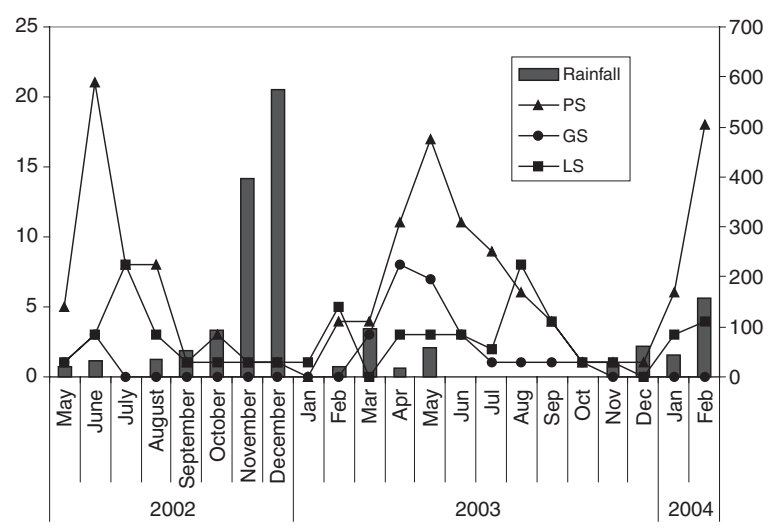

Fig 4 Population dynamics of three rodent species (LS, Lophuromys flavopunctatus; GS, Grammomys dolichurus and PS, Praomys delectorum) in the Magamba Forest Reserve in north-east Tanzania

strategies of rodents (Leirs et al., 1994). It has been suggested that quality and quantity of food are important factors influencing reproductive activity in rodents (Field, 1976) although quality is considered more important.
Correlation between reproductive activity and rainfall has been reported for other species of rodents including M. natalensis (Leirs, 1992; Leirs et al., 1994). These variations in reproductive activity, particularly on the onset and termination of the reproductive period, affect recruitment and survival, which are key factors in population dynamics (Solomon, 1969). For many rodent species, changes in population density have been shown to depend strongly on the onset and duration of rainfall (Delany, 1986). Rainfall is a density-independent factor influencing rodent populations in Africa (Leirs, 1992; Leirs et al., 1994). It affects primary productivity and indirectly, the small mammal population dynamics (Jaksic et al., 1997). The three species in the current study were influenced by the seasonal changes brought about by rainfall despite habitation of a relatively stable environment in the forest reserve. Delany (1971) reported that when rainfall is extensive, reproduction might occur throughout the year. Within the Magamba Forest Reserve wet conditions persist, but the dietary requirements of the three species (seeds, insects, vegetative materials, etc.) obviously change in quality and quantity within the seasons, with abundance and quality increasing during the wet season. Such variations inevitably determine the peak period of births and survival of the three species, which is reflected in their population dynamics.

Earlier studies in agricultural land neighbouring the Magamba Forest Reserve have shown drastic rises and declines of the multimammate rats, M. natalensis, where densities reached $>200$ rodents ha ${ }^{-1}$ (Makundi et al., 2003) compared with the low densities ( $<25$ animals $\mathrm{ha}^{-1}$ ) of the three species in this study. It is obvious that the forest offers more predictive conditions compared with the unstable environment of the surrounding cultivated fields. As variations between dry and wet seasons are not very pronounced in montane rain forests, the primary productivity on which rodents depend is assumed not to fluctuate to extremes in between seasons. Therefore, the much more stable environment in the Magamba Forest Reserve would minimize density fluctuations of the species annually and between seasons. Densities in the forest were generally low $\left(<10\right.$ animals $\mathrm{ha}^{-1}$ for $L$. flavopunctatus, $<10$ animals ha ${ }^{-1}$ for G. dolichurus and $<25$ animals ha ${ }^{-1}$ for $P$. delectorum) during the entire study period. Leirs (2003) and Leirs et al. (1997) have argued that rodents with stable patterns of population fluctuations are kept within restricted limits by density-dependent mechanism. The current study suggests that the three species have 
different microhabitats requirements within the forest and probably these impose temporal limitations on population growth. Further studies to identify the microhabitat requirements of the species are necessary. Praomys delectorum, inhabit moist savannah-forest mosaics and montane areas, but humid heavily shaded forest floor or secondary scrub is preferred (Kingdon, 1997). Grammomys dolichurus is predominantly a woodland/forest species and mainly inhabits moister vegetation (Kingdon, 1997), but it has also been reported in grasslands and cultivated fields (Taylor, 1998). Lophuromys flavopuncatus is a common rodent species in the Magamba Forest Reserve, and is also found in the cultivated and agro-forestry areas surrounding the reserve. Limitations of available and suitable habitats and fragmentation of populations of the three species may be caused by the long-term effects of human activities imposed on the forest reserve. Such activities, including excessive deforestation and agriculture, have environmental consequences including declining amount of rainfall and its reliability. The spatial distribution, breeding and population dynamics of the three species are most likely to be affected.

\section{Acknowledgements}

We wish to express our gratitude to Sokoine University of Agriculture for the unconditional permission to conduct these studies in the Western Usambara Mountains, northeast Tanzania. The studies were financially covered by the SUA-VLIR Programme, through Component 3 (Rodent Research). Without the support of the programme, these studies would not have been realized. The assistance rendered by the Coordinator of the SUA-VLIR Programme, Dr Peter Mtakwa, for smooth implementation of the work is highly acknowledged. The SUA Pest Management Center facilitated procurement of field and laboratory equipment. We appreciate the assistance provided by the Director, Prof. Robert S. Machang'u and various other staff.

\section{References}

Delany, M.J. (1971) The biology of small rodents in Mayanja

Forest, Uganda. J. Zool. (Lond.) 165, 85-129.

DelAny, M.J. (1986) Ecology of small mammals in Africa. Mammal Rev. 16, 1-41

FieLD, A.C. (1976) Seasonal changes in reproduction, diet and body composition of two equatorial rodents. E. Afr. Wildl. J. 13, 225-236.
HAPPOLD, D.C.D. (1977) A population study on small mammals in the tropical rain forest of Nigeria. La Terre et la Vie 31, 385458.

HAPPOLD, D.C.D. (2001) Ecology of African small mammals. Recent research and perspectives. In: African Small Mammals (Eds C. Dennys, L. Granjon and A. Poulet). IRD Editions, Paris.

Hubert, B., Courturier, G., Poulet, A. \& Adam, F. (1981) Les conséquences d'un supplément alimentaire sur la dynamique des population de ronguers au Senegal. Les cas de Mastomys erythroleucus en zone Sahélo-Soudanenne. La Terre et la Vie 35, 73-96.

Jaksic, F.M., Silva, S.I., MeserVe, P.L. \& Gutienez, J.R. (1997) A long-term study of vertebrate predator responses to an El Nino (ENSO) disturbances in western South America. Oikos 78, 341354.

Kingdon, J. (1997) The Kingdon Guide to African Mammals. Academic Press Ltd, London.

LeIRs, H. (1992) Population ecology of Mastomys natalensis (Smith, 1834) multimammate rats: possible implications for rodent control in Africa. PhD Thesis, University of Antwerp, Belgium.

LeIRS, H. (2003) Management of rodents in crops: the Pied Piper and his orchestra. In: Rats, Mice and People: Rodent Biology and Management (Eds G. R. Singleton, L. A. Hinds, C. J. KreBS and D. M. SPRATT). Australian Centre for International Agricultural Research, Canberra.

Leirs, H., Verhagen, R. \& Verheyen, W. (1994) The basis for reproductive seasonality in Mastomys rats (Rodentia: Muridae) in Tanzania. J. Trop. Ecol. 10, 55-66.

Leirs, H., Stenseth, N.C., Nichols, J.D., Hines, J.E., Verhagen, R. \& VERHEYEN, W. (1997) Stochastic seasonality and none linear density dependent factors regulate population size in an African rodent. Nature 389, 176-180.

MaKundi, R.H., KILonzo, B.S. \& Massawe, A.W. (2003) Interaction between rodent species in agro-forestry habitats in the western Usambara mountains, northeast Tanzania, and its potential for plague transmission to humans. In: Rats, Mice and People. Rodent Biology and Management (Eds G. R. Singleton, L. A. Hinds, C. J. KrEBS and D. M. SPRATT). Australian Centre for International Agricultural Research, Canberra.

Solomon, M. (1969) Population Dynamics. Edward Arnold (Publishers) Ltd, London.

TAYLOR, P. (1998) The Smaller Mammals of KwaZulu-Natal. University of Natal Press, Pietermaritzburg.

TAYLOR, K.D. \& GREEN, M.G. (1976) The influence of rainfall on diet and reproduction in four African rodent species. J. Zool. (Lond.) $180,367-389$.

White, G.C., Anderson, D.R., Burnham, K.P. \& OTIS, D.C. (1982) Capture-Recapture and Removal Methods for Sampling Closed Populations. Los Alamos National Laboratory, Los Alamos, NM.

(Manuscript accepted 19 May 2006)

doi: 10.1111/j.1365-2028.2006.00667.x 